\title{
Sustainable Supply Chain for Disaster Management: Structural Dynamics and Disruptive Risks
}

\author{
Mahmud A. Shareef \\ School of Business \& Economics, North South University, Bangladesh \\ Email: mahmud_akh@yahoo.com \\ Yogesh K. Dwivedi (Corresponding Author) \\ Emerging Markets Research Centre (EMaRC), School of Management \\ Swansea University Bay Campus, UK \\ Email: ykdwivedi@gmail.com
}

\begin{abstract}
Vinod Kumar
Sprott School of Business, Carleton University, Canada

Email: vinod.kumar@carleton.ca
\end{abstract}

D. Laurie Hughes

Emerging Markets Research Centre (EMaRC)

School of Management, Swansea University Bay Campus

Fabian Way, Swansea, Wales, UK

Email: D.L.Hughes@Swansea.ac.uk

\section{Ramakrishnan Raman}

Symbiosis Institute of Business Management, Pune \& Symbiosis International

(Deemed) University, Pune, India

Email: director@sibmpune.edu.in 


\title{
Sustainable Supply Chain for Disaster Management: Structural Dynamics and Disruptive Risks
}

\begin{abstract}
This study explores the operational characteristics of supply chain operations during disaster scenarios within Bangladesh and the profound impact of disruption risks due to poor operational effectiveness and structural dynamics within the supply chain network. Via the analysis of representative case studies and interviews with over 500 stakeholders, we identify and analyse the many structural and administrative complexities and subsequent disruption risks surrounding the utilisation of traditional supply chain infrastructures for emergency disaster scenarios. The findings illustrate the severe impact of poor demand estimation, inadequate selection of supply items, bureaucratic and extended chain of administration, poor central coordination among the participating organizations, absence of interoperability, poor infrastructure, and lack of information sharing. We propose a new emergency supply chain infrastructure to mitigate these threats offering contribution to the literature as well as support to disaster relief efforts within Bangladesh.
\end{abstract}

Keywords: Supply chain, Disruption risks, Structural dynamics, Resilience, Ripple effect, Sustainability

\section{Introduction}

Within many developing counties, government and non-government organizations (NGOs) operate and maintain supply chains to help vulnerable sectors of the population to meet their basic needs (Beamon \& Balcik, 2008; Dwivedi et al., 2018). These managed supply chains are created to transport and distribute food, water, sanitation and medicines throughout many parts of the world (Alessandra, 2012; Balcik et al., 2010; Shareef et al., 2019). Supply chains consist of a number of interrelated and dynamically changeable structures where the adaptation of one structure can effect changes within other interconnected structures (Ivanov 2010). This concept of structural dynamics is relevant within modern supply chains where the interconnected elements are generally required to be agile and flexible where changes in one component may ripple through the chain impacting other related structures. Within an emergency scenario, where disasters such as: hurricanes, flash floods, fire and famine can greatly impact the population and environment, national governments and NGO's step in to operate and manage emergency supply chains (ESCS). However, all too often these ESCs break-down as governments seem unable to react and coordinate the required logistics due to poor management, inefficiencies, negative structural dynamics related issues and disruption risks (Dwivedi et al., 2018).

Supply chain parameters and associated operational threats are significantly different within ESCs where interoperability among organizations to mitigate disruption risks can play a crucial role (Balcik \& Beamon, 2008; Shareef et al., 2018). Managing an ESC during disaster scenarios is complex involving numerous problems relating to: procurement and logistics, network maintenance and support, inventory management, accurate and timely data communication (Dwivedi et al., 2018). The development and 
management of an ESC during any disaster scenario can be subject to a number of threats to effective operations, collectively termed - disruption risks. The impact of significant natural disasters can cause multiple disruptions in situations where a number of these risks are not mitigated. This topic has featured widely within the supply chain literature, where the disaster itself is posited as a substantial reason for the occurrence of disruption threats within emergency situations (Dolgui et al. 2018; Kumar et al., 2020; Sodhi et al. 2012). Generally studies have tended to omit to explore the inability of organizations to operate and manage ESCs effectively and to mitigate the many disruption risks that can severely affect operational effectiveness (Cui et al., 2012; Blackhurst et al., 2005; Dwivedi et al., 2018; Kouvelis \& Li, 2012; Shareef et al., 2018).

This study focusses on supply chain operations under humanitarian disaster scenarios within Bangladesh, an emerging economy that has experienced a long history of natural disasters. The country faced 219 separate significant natural disasters between 1980 and 2008, suffering from earthquake, drought, riverbank erosion, tsunami, fire, hurricane and floods with resulting severe disruption to society, the economy and loss of life (ADRC 2019). The response by government and NGOs is often reliant on the established but limited network of existing supply chains (Dwivedi et al., 2018; McLachlin \& Larson, 2011) and as such often fails to deliver sustainable solutions to the Bangladeshi people. Although the literature has focussed on many of the economic and social challenges impacting the lives of the people living in Bangladesh (Moktadir et al., 2018; Sarker et al., 2017), studies have generally omitted to offer insight from an ESC perspective (Dwivedi et al., 2018). In alignment with recommendations from previous studies (Dwivedi et al., 2018; Ivanov et al., 2010), we address this issue from a threat analysis perspective where we review the disruption risks within the Bangladesh context.

This study analyses a number of intertwined themes in the development of greater contextual understanding of existing structural dynamics within ESCs and reasons for increased threat of disruption risks. We develop the necessary mapping of the inherent flaws and risks of ESHs in Bangladesh and consider the impact of ripple effects within the supply chain. This research analyses the sustainable structural networks of ESHs to develop mitigation strategies for the many disruption risks. We collect data from 500 Bangladeshi stakeholders from the disaster affected areas to include: organizational authorities, volunteers and a number of affected citizens. This research aims to provide deep insight to the problems of balancing structural dynamics and disruption risks in Bangladesh in the management and operation of ESC's within an existing supply chain infrastructure.

We elaborate on the aforementioned issues and propose the following research questions:

1. What are the potential reasons of disruption risks in existing structural dynamics of emergency supply chain?

2. How can flaws and risks within structural dynamics be contrasted and mapped for emergency supply chains within Bangladesh

3. What are the changes needed within sustainable structural networks of emergency supply chains that reflecting the potential disruption risks? 
The remainder of this study is structured as follows: Section 2 details the relevant literature within the areas of ESC, disruption risks and structural dynamics; Section 3 discusses the underlying rational for the research design; Section 4 and 5 discusses the data collection process and analysis of results; the paper is concluded within Section 6.

\section{Literature Review}

The key complexities of humanitarian supply chains have been explored within the literature, where studies have considered the varying perspectives of administrative conflicts, operational risks, driving parameters, location facilities, and overall management (Bui et al., 2000; Dubey et al., 2014). The literature has affirmed that disruption risks and consequent ripple effects should be thoroughly addressed and explored to design suitable supply chain structural dynamics (Altay \& Labonte, 2014; Dolgui et al., 2018; Hu et al., 2013; Wamba et al., 2018). For any ESC, disruption risks can significantly damage the efficiency and integrity of the supply chain particularly during the initial critical stages (Balcik et al., 2010; Bui et al., 2000; Hendricks and Singhal 2005. Table 1 details the range of disruption risks to the operation of ESCs that have been analysed within previous studies.

Table 1: Disruption risks to ESC

\begin{tabular}{|l|l|l|}
\hline ESC risk type & ESC risk description & Reference \\
\hline Demand side risks & $\begin{array}{l}\text { Threats from demand uncertainty and } \\
\text { volatility. }\end{array}$ & $\begin{array}{l}\text { Ambulkar et al., (2015); Dreyer et } \\
\text { al., (2016); Sodhi, (2005). }\end{array}$ \\
\hline Supply side risks & $\begin{array}{l}\text { Threats to timely product and material } \\
\text { supply. }\end{array}$ & $\begin{array}{l}\text { Chopra \& Sodhi, (2004); Wagner \& } \\
\text { Bode, (2008). }\end{array}$ \\
\hline $\begin{array}{l}\text { Regulatory, legislative and } \\
\text { administrative risks }\end{array}$ & $\begin{array}{l}\text { Disruption to ESC due to localised threats } \\
\text { relating to rules and regulations, laws } \\
\text { and political factors. }\end{array}$ & Dwivedi et al., (2018). \\
\hline Infrastructure risks & $\begin{array}{l}\text { Threats to supply chain operations from } \\
\text { localised infrastructure related issues } \\
\text { that may impede timely logistics. }\end{array}$ & $\begin{array}{l}\text { McKinnon, (2006); Shareef et al. } \\
\text { (2018), catastrophic risks (Coleman, } \\
\text { 2006); Knemeyer et al., (2009). }\end{array}$ \\
\hline Interoperability risks & $\begin{array}{l}\text { Threats to ESC due to operability issues } \\
\text { among the supply chain entities, } \\
\text { impacting efficiency and integrity. }\end{array}$ & $\begin{array}{l}\text { Dwivedi et al., (2018); Dubey et al., } \\
\text { (2017). Dubey et al. (2019c) }\end{array}$ \\
\hline Storage risks & $\begin{array}{l}\text { Disruption to ESC due to inability to } \\
\text { effectively store critical supplies at key } \\
\text { locations near the point of need or for } \\
\text { timely logistics. }\end{array}$ & $\begin{array}{l}\text { Cui et al., (2012); Shareef et al. } \\
\text { (2018). }\end{array}$ \\
\hline Facility location risks & $\begin{array}{l}\text { Threats and uncertainties due to "facility } \\
\text { failure" and impact on ESC switching to } \\
\text { fall-back options. }\end{array}$ & $\begin{array}{l}\text { Berman et al., (2007); Lee \& } \\
\text { Billington, (1993); Li et al., (2013); } \\
\text { Lim et al., (2013). }\end{array}$ \\
\hline
\end{tabular}

Rao and Goldsby (2009) noted that decision making risk has a significant impact on supply chain performance which is crucial for ESC design during disaster scenarios. Several authors highlight that natural disasters can cause severe risks to the integrity of supply chains especially in the supply, demand, 
and distribution phases (Manuj \& Mentzer, 2008; Oke \& Gopalakrishnan, 2009; Tang \& Tomlin, 2008). Risks to the integrity of supply, demand, procurement and facility location, can cause ripple effects in the launching of an ESC (Balcik et al., 2010; Bui et al., 2000). The study undertaken by Cui et al. (2012) posited that reliable facility location is critical for ESCs to alleviate disruption risks and emphasised that the resulting ripple effect may create an overall catastrophe within the wider supply chain.

Within emergency scenarios, factors such as efficiency and cost effectiveness tend to exhibit lower criticality while resilience, efficiency and responsiveness are deemed to be of higher importance (Blackhurst et al., 2005; Dubey et al., 2017; Wagner \& Bode, 2008). ESC resilience is extremely important when developing mitigating measures for disruption risks (Campos et al., 2019; Dubey et al., 2017; Gopal \& Thakkar, 2016; Lewis et al., 2013). Researchers have posited the pragmatic assessment that alternative contingency options should be developed, even though these may not be in alignment with cost and efficiency criteria. Thus, highlighting the criticality of minimizing lead-time from procurement to distribution to achieve the ESC goals (Balcik \& Beamon, 2008; Shareef et al., 2018). Researchers have posited the benefits of this trade off where alternate options and contingency planning for facility location, procurement and logistics, outweigh the basic elements of cost and efficiency within ESC scenarios (Balcik \& Beamon, 2008; Shareef et al., 2018).

In the development of sustainable ESCs, the structural dynamics of the network should be analysed in the light of value, social environmental and economic perspectives. Prior design and planning of the supply network with alternative sources to tackle ripple effect are key issues for ESCs (Balcik et al., 2010; Dubey et al., 2017; Dwivedi et al., 2018; Tayal et al., 2017; Sinha et al., 2019b). Consequently, several studies have advocated for proactive design of structural dynamics of ESCs (Cui et al., 2012; Norrman \& Jansson, 2004). Considering its unique characteristics, distinct purpose, mission, and objective, researchers have suggested that ESC structural dynamics should be designed to reflect the process, operations and facilities of the supply chain (Balcik et al., 2010; Davis et al., 2013; Dwivedi et al., 2018; Sinha et al., 2019a). The research undertaken in Ivanov et al. (2016) has developed recovery policies from a structural dynamics perspective in conjunction with operational performance and supply chain efficiency. Several models such as: inventory management model (Hishamuddin et al., 2013), sourcing strategy (Gupta et al., 2015), reliable facility location (Sodhi et al., 2012), reliable back-up supplier (Hou et al., 2010; Lim et al., 2013), have recommended that conceptual framing of ESCs exhibits different sets of risks and thus, should be analysed with unique assumptions of structural dynamics. This study posits the view supported by the literature, that supply chains dealing with disaster scenarios are significantly different from traditional supply chains and can be quantified in terms of threats to supply chain integrity and magnitude of disruption risks. Significantly, the literature has omitted to offer key insight to the complexities, intertwined ripple effect and structural dynamics of ESCs within a Bangladesh context. This study seeks to fill this gap in the literature and offers new perspective on this key topic.

\section{Theoretical Background}

The high level research framework utilised within this study is presented in Figure 1. The data collection and analysis approach within this study builds on the previous research from Shareef et al (2018) and 
Kahn (2008) where these studies assessed the suitability of existing supply chain networks for relief distribution in Bangladesh and studies that focus on aspects of trust; resilience and transparency within humanitarian operations management and humanitarian supply chains (Dubey et al. 2020; Gunasekaran et al. 2018). This theme is continued within the research where we analyse a number of relevant case studies to highlight many of the complexities and limitations of standard supply chains to cater for emergency scenarios. We develop this insight further by conducting interviews with a range of key stakeholders to ascertain detailed participant views on many of the disruption risks within disaster situations. We analyse five major disaster incidents within Bangladesh where regular supply chain networks are used to conduct emergency procurement and distribution of critical support. From the detailed analysis of these five disaster cases, we reveal the key threats to supply chain integrity from the interchanging structural dynamics of ESCs. This analysis reveals the critical elements of disruption risk within each of the cases and highlights the key parameters aligned with supply chain sustainability.

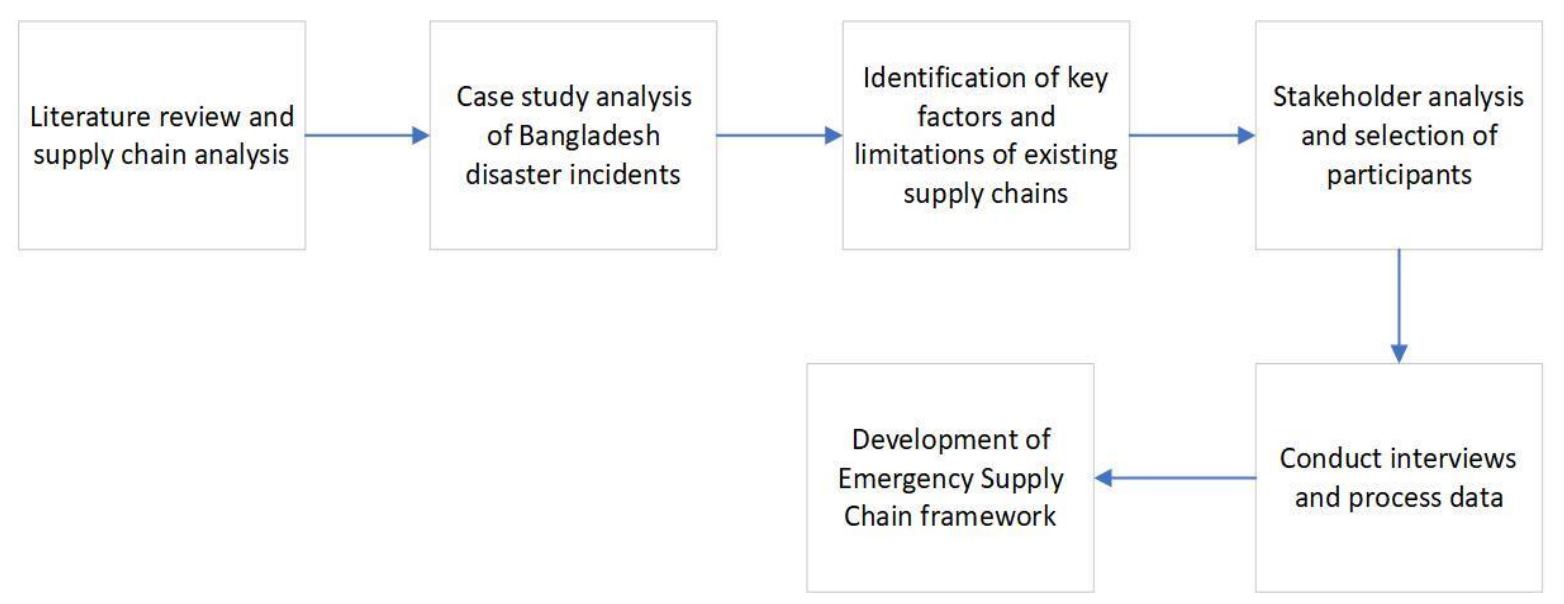

Figure 1: Research framework.

The participants selected for this study are key stakeholders involved within a number of aspects of the Bangladeshi humanitarian supply chain. These were selected from a range of key ministries and representative organizations, each offering valuable perspective on the complexities of ESCs. The participants are responsible for a number of key roles supporting emergency initiatives across disparate locations within a number of districts within Bangladesh: central authority in the department of disaster management (DDM), district relief and rehabilitation officers (DRROs) (main authority for relief procurement and distribution in 64 districts of Bangladesh), project implementation officers (PIOs) working at root level, Non-government organizations (NGOs), donor agencies, voluntary organizations, local political authorities and elected bodies.

The data from the interviews was analysed and processed. The ESC framework was developed based on the analysis of the key factors from the case studies and insights gained from the participant interviews. 


\section{Methodology}

This study has reviewed several cases of disaster incidents occurring over many years within Bangladesh and analyses the ability of existing supply chain networks to maintain effective operations during disaster scenarios. Extensive interviews were conducted among the key stakeholders and participating members of humanitarian supply chains to analyse and address the many problems, potential loopholes and recommendations for change. The qualitative based primary data was collected from key stakeholders and analysed then processed to assess the views, judgements and feelings of participants working within the many critical elements of the supply chain, each offering their insightful feedback on the ability of existing infrastructure to support disaster scenarios. The detailed process of data and information collection is explained in the successive sections.

\subsection{Case Background}

Since 2015 the Bangladeshi government in conjunction with many foreign donors, NGOs, voluntary organizations, and local elected bodies, have launched several emergency relief distribution operations through an established supply chain network. From these multiple operations, five major relief distributions through traditional supply networks have been analysed to ascertain the problems, weaknesses, and disruption risks with potential ripple effects. Demand for any geographical region is estimated based on historical data (Shareef et al., 2018). In any given year - prior to any disaster, key disaster relief supplies are purchased centrally by the director of DDM and stored in three centrally located warehouses in the southern and central districts of the country. This procurement planning, quantity assessment, item selection and storage are conducted independently of any specific disaster. Food items, particularly rice and construction materials such as Corrugated Iron (CI) sheets are allocated to each district (64 in total) and delivered to the store house maintained by the district commissioner (DC). Although the DC performs the top administrative position (for legacy colonial reasons) they do not function as the executive administrator to operate relief distribution. The DRRO is the central authority in terms of responsibility to operate relief distribution. Consequently, during a disaster scenario when time is the most critical issue, the DRRO has to get permission from the DC to receive the supply of relief materials. After receiving the delivery of supplies, the DRROs distribute supplies at the sub-district level (Upazilas) as per the demand requisition letter prepared by the root level relief PIO. Finally - foreign donors, NGOs, and private voluntary organizations generally distribute relief to the people in need. However, in some instances the DC coordinates directly with each of these organizations. The following case studies illustrate the supply chain operation in practice and key elements are discussed in the light of structural dynamics and disruption risks.

\section{Flood disaster (2004)}

Flash floods are particularly common within Bangladesh and can affect significant numbers of people who live within the flood plain. These incidents frequently create significant disaster scenarios requiring urgent relief distribution from government and NGOs. Traditionally, relief distribution for this kind of disaster is managed by the aforementioned supply networks. In June 2004, over 25,000 families were rendered 
homeless by riverbank erosion in 16 districts in the northern zone of Bangladesh. Government did not launch any specific procurement effort for this relief distribution. Supply of materials such as $\mathrm{Cl}$ sheets and water purification tablets were pre-estimated and stored centrally in Dhaka (far from the affected areas). Rice was stored in the northern districts; however, due to the flood storage markets (Godown) were affected. Demand of rice and water purification tablets increased rapidly which could not be met due to several weaknesses relating to supply chain structural dynamics (Shareef et al., 2018). The key weaknesses in supporting the relief effort from this case study include: poor estimation, extended demand with ripple effect, poor logistics management (particularly transportation), underdeveloped or broken infrastructure, weak interoperability, administrative conflicts and poor communication. Ultimately, the traditional supply chain in operation at the time, was unable to meet the urgent demand from the affected people and was neither cost effective nor responsive to the needs of Bangladeshi citizens (Kahn, 2008).

\section{Cyclone Sidr (2007)}

This particular cyclone had a devastating impact on Bangladesh in November 2007 with an estimated 5,000 deaths directly attributed to the storm (Disaster Management Bureau, 2015). Due to the cyclone, more than ten districts with ten million people were severely impacted needing urgent relief including: food, non-food items, shelter and pure water. Disruption risks and the consequent ripple effect were clearly observed within inventory management, facility location, demand estimation, and distribution process. The Bangladeshi government reported that they tried their best to tackle and reduce damage however, certain obvious constraints in the traditional structure of the existing supply chains were exposed (Dwivedi et al., 2018). Among the numerous multidimensional issues on the ground and associated risks to people, the fundamental problems were cited as: poor proximity of facility locations, shortage of goods, long lead times due to bureaucracy, inaccurate estimation, inter-organizational conflicts, presence of too many supply chain nodes and separate disparate networks, poor infrastructure, poor management of information and inadequate distribution processes (Shareef et al., 2018.). These issues are connected with demand, supply, process, and control.

\section{Cyclonic Storm Roanu (2016)}

Although this was described at the time as a relatively weak tropical cyclone, this disaster severely impacted numerous Bangladeshi coastal areas such as: Sandwip, Hatia, Kutubdia, Sitakundu and Feni with severe flooding. Around one million people were affected needing urgent water purification facilities, clean water supplies and dry food. During the disaster, problems were highlighted in the management of the emergency supply chain, delegation of authority, coordination, organizational conflicts and poor functional process (Dwivedi et al. 2018; Kahn, 2008; Shareef et al., 2018). Storage of dry food and water purification systems was poorly for effective distribution to impacted areas. Lack of inter-organizational coordination increased procurement-2-distribution lead time to excessive levels. Demand was not properly estimated as PIOs' (field officers) suggestions were not considered properly; rather it was controlled by a remote central authority (Dwivedi et al. 2018). 


\section{Landslide (2017)}

On June 12, 2017 heavy monsoon rain triggered a series of landslides in three remote districts of Bangladesh. Around one hundred fifty people were killed, and one hundred thousand people were made homeless without adequate food and water. Subsequently, the people impacted required urgent food and shelter supplies. Shelter items were located in storage near to the disaster location. However, food supplies were severely delayed as the provisions located in nearby storage facilities proved to be inadequate. Network and nodal points of traditional supply chains also proved to be inefficient for the distribution process due to: poor immediate supply, distribution from single network, authority delegation to direct filed officers and executive body, lack of closely located alternative facility locations, adequate transportation facility, Information sharing among the organizations (Islam et al., 2017).

\section{Flood (2017)}

A devastating flood occurred within Bangladesh in July 2017 which disrupted the lives of around 6 million people. The impacted areas included northern and eastern zones comprising 1200 unions of 183 upazilas under 31 districts. Interestingly, supply of food and materials was reported as adequate, with excess provisions reported in some areas. However, many people did not get the required supplies due to the inherent structural problems of emergency distribution networks (Kahn, 2008). Among many issues, the most challenging constraints were: serious and compounding problems concerning coordination amongst distribution agencies, administrative problems along the decision making network from central authority to district authority to sub-district level relief officers and local NGOs, location of facility/storage, unavailability of sufficient and urgent transportation, relief item selection and availability, and interference of local elected bodies.

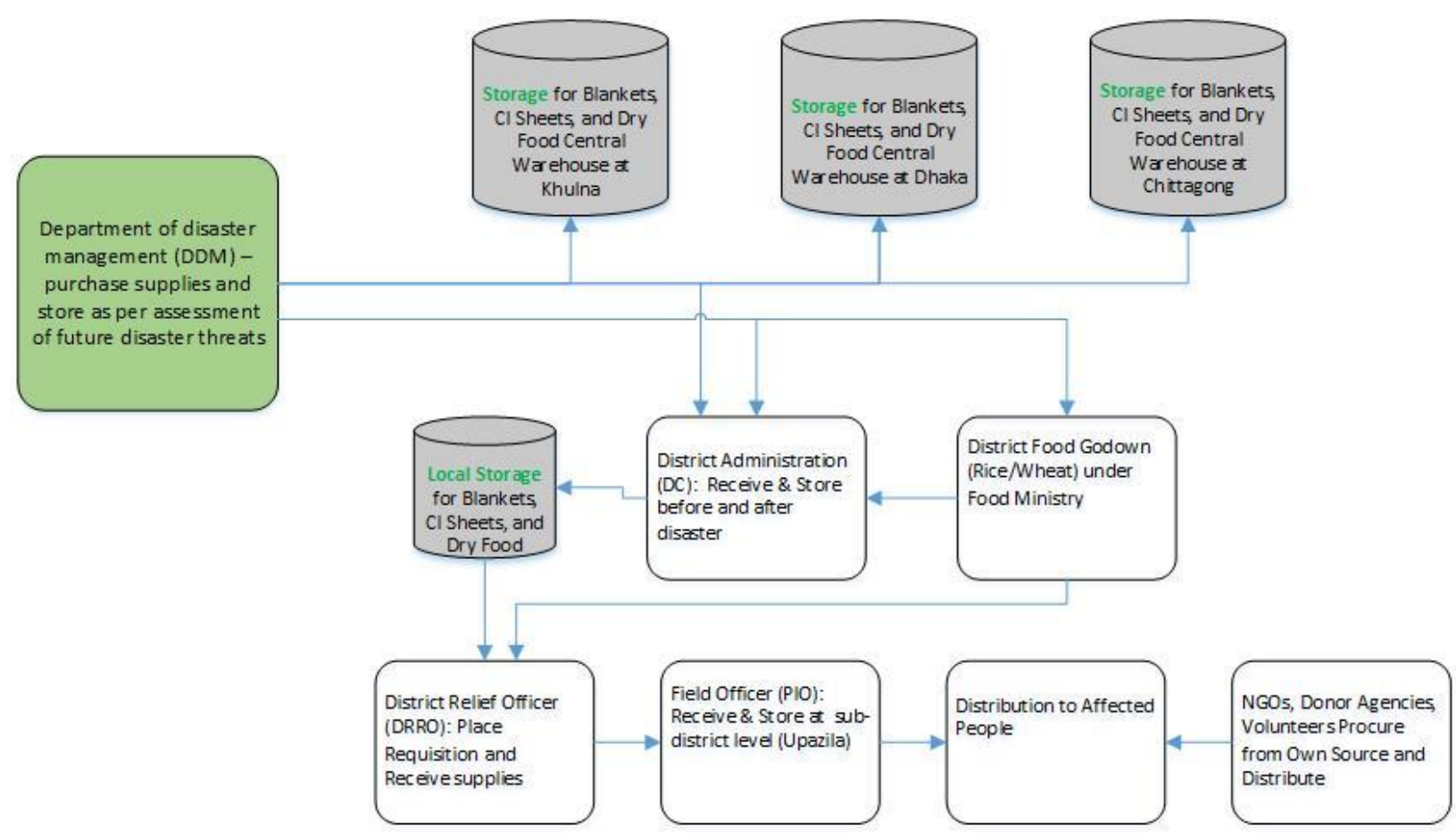

Figure 2: Existing process for supply chain operation within a disaster scenario 
The underlying process for the existing supply chain outlined within the selected case studies is highlighted in Figure 2. The key steps and descriptions are detailed in the next paragraph.

Initial authorisation authority is given by the Director of DDM (located in Dhaka) to procure supplies. The estimation of key supplies is calculated based on historical data and budgeted for periodic relief distribution. The DDM stores these non-food items within three central warehouses then distributes to the 64 districts based on historical need assessment (not conducted by field officers, DRRO or PIO). The supplies are directly distributed to the district commissioner (DC) and stored under DC's local store facility. The DC by administrative authority holds the highest district level position. Once authority is received, the DRRO is responsible for distribution at the sub-district level. Food items such as rice and wheat are stored in district level Godown under control of the ministry of food. The DRRO does not have authority to procure, store, and distribute these items directly but receives supplies as needed. Traditionally, field officers (PIOs) operate under authority of the DRRO. They are the root level implementing officers. They should receive supplies as per filed assessments. However, it is often imposed by the higher authority rather than actual assessment. NGOs, donor agencies, and other voluntary organizations working in relief distribution operation procure and distribute their items directly often without coordination among the distributing organizations. Supplies are distributed to the affected people. Logistics and transportation are generally poor and not designed to support an emergency situation. Local elected bodies tend to interfere in the distribution process further exacerbating the problem.

The analysis of existing supply chains to cope with disaster scenarios, raises some obvious structural problems in terms of networking infrastructure, organizational coordination, demand assessment, facility location, inventory management and transportation of supplies. Information sharing and interoperability of process and control are particularly inefficient during an emergency incident. These issues and subsequent disruption risks and ripple effects have been highlighted within existing studies, supporting the inability of governments to adequately gear up existing supply chains to cater for disasters (Blackhurst et al., 2005; Dolgui et al., 2018; Sodhi et al., 2012; Tomasini \& Van Wassenhove, 2009; Wagner \& Bode, 2008). Common disruption risks relating to: demand and supply side regulatory problems, legislative, and administrative, communication and coordination between donors and beneficiary stakeholders, infrastructure and coordination of supplies, interoperability and storage, facility and location - are clearly observed within disaster supply chains (Dwivedi et al. 2018; Gunasekaran et al. 2018). These risks materialise due to a number of factors, namely: inappropriate supply chain design, poor networking, bureaucratic issues within procurement and distribution, authority and responsibility delegation, lack of organizational coordination and interoperability, weak and inappropriate needs assessment and forecasting.

\subsection{Data Collection}

In order to develop substantial depth and engender a diverse base of viewpoints from participants, a total of 500 separate interviews were held. The interviews were organised to reveal a rich reflection on the 
structural dynamics and disruption risks associated with ESCs during disaster scenarios. The participant details are listed in Table 2.

Table 2: Summary of Data Source

\begin{tabular}{|c|c|c|c|}
\hline Stakeholder & $\begin{array}{l}\text { No } \\
\text { Interviewed }\end{array}$ & Role/Responsibility & Authority (Inter-organization) \\
\hline Director, DDM & 1 & $\begin{array}{l}\text { Formalise budget from Ministry } \\
\text { Select item with Ministry } \\
\text { Purchase supply materials (Other than rice } \\
\text { and wheat). } \\
\text { Store materials in three central } \\
\text { warehouses. } \\
\text { Allocate relief items to different districts }\end{array}$ & $\begin{array}{l}\text { Select amount of allocation for } \\
\text { different districts } \\
\text { Evaluate and adjust demand } \\
\text { requisition received from } \\
\text { DC/DRRO/PIO } \\
\text { Control demand and supply } \\
\text { Decide schedule to allocate with } \\
\text { DC/DRRO }\end{array}$ \\
\hline DDM Office & 10 & $\begin{array}{l}\text { Process requisition orders received from } \\
\text { different districts } \\
\text { Analyse demand orders based on historical } \\
\text { data, Communicate with districts DRRO } \\
\text { office }\end{array}$ & $\begin{array}{l}\text { Expedite or delay delivery } \\
\text { Communicate with central } \\
\text { warehouse }\end{array}$ \\
\hline $\begin{array}{l}\text { Ministry of } \\
\text { Food }\end{array}$ & 10 & $\begin{array}{l}\text { Procure food items - rice/wheat etc. at } \\
\text { different times. } \\
\text { Maintain quality of stored food items } \\
\text { Delivery to DC/DRRO/PIO as per approved } \\
\text { requisition } \\
\text { Maintain transportation }\end{array}$ & $\begin{array}{l}\text { Evaluate and adjust demand } \\
\text { requisition for rice and wheat } \\
\text { received from DC/DRRO/PIO } \\
\text { Control procurement time and } \\
\text { amount. } \\
\text { Instruct amount of inventory to } \\
\text { be stored in different Godown } \\
\text { Control delivery with DDM/DC }\end{array}$ \\
\hline $\begin{array}{l}\text { DRRO and } \\
\text { other } \\
\text { employees of } \\
\text { DRRO office }\end{array}$ & 125 & $\begin{array}{l}\text { Collect demand assessment report from } \\
\text { PIOs } \\
\text { Place demand to DDM } \\
\text { Communicate with DC to collect relief } \\
\text { martials } \\
\text { Collect information about number of } \\
\text { affected people and type and magnitude of } \\
\text { damage from PIO } \\
\text { Distribute relief items to PIOS } \\
\text { Coordinate distribution with PIOs } \\
\text { Share information with DCs and DDM }\end{array}$ & $\begin{array}{l}\text { Adjust demand for different PIOs } \\
\text { and place it to DDM and DC } \\
\text { Decide schedule and amount to } \\
\text { allocate to PIOs } \\
\text { Collect rice/wheat from local } \\
\text { food Godown with Ministry of } \\
\text { food/DC }\end{array}$ \\
\hline $\begin{array}{l}\text { DC and other } \\
\text { employees of } \\
\text { DC office }\end{array}$ & 55 & $\begin{array}{l}\text { Store received items from DDM in district } \\
\text { store room and maintain quality } \\
\text { Maintain communication with DRRO, PIO, } \\
\text { and other working organizations during } \\
\text { disaster } \\
\text { Allocate relief items to DRRO office } \\
\text { Process DRROs' requirements for items } \\
\text { stored under DC office and food items from } \\
\text { district food Godown } \\
\text { Process further requisitions from DRRO } \\
\text { office to Ministry }\end{array}$ & $\begin{array}{l}\text { Evaluate and adjust demand } \\
\text { requisition received from DRRO } \\
\text { Control delivery and DRRO office } \\
\text { Decide schedule and amount to } \\
\text { allocate relief to DRRO } \\
\text { Head of all administrative } \\
\text { operation in the district level }\end{array}$ \\
\hline
\end{tabular}




\begin{tabular}{|c|c|c|c|}
\hline NGO & 30 & $\begin{array}{l}\text { Demand forecast and distribution } \\
\text { May communicate with district government } \\
\text { offices such as DC/DRRO } \\
\text { Collect information from affected areas }\end{array}$ & $\begin{array}{l}\text { Select supply products } \\
\text { Procure and store } \\
\text { Distribute } \\
\text { Select amount of relief items } \\
\text { Manage own logistics }\end{array}$ \\
\hline $\mathrm{PIO}$ & 60 & $\begin{array}{l}\text { Forecast/assess actual demand for affected } \\
\text { people } \\
\text { Place demand requisition to DRRO office } \\
\text { Receive relief items from DRRO/food } \\
\text { Godown } \\
\text { Distribute relief items directly to the } \\
\text { affected people } \\
\text { Manage transportation }\end{array}$ & $\begin{array}{l}\text { Decide amount of distribution } \\
\text { for each affected family in } \\
\text { consultation with local elected } \\
\text { bodies } \\
\text { Estimate actual demand from } \\
\text { root level }\end{array}$ \\
\hline $\begin{array}{l}\text { Local Elected } \\
\text { members }\end{array}$ & 35 & $\begin{array}{l}\text { Help PIOs to estimate actual demand } \\
\text { Help PIOS to distribute relief items } \\
\text { Help PIOs to manage local transportation } \\
\text { Share information with government and } \\
\text { NGOs }\end{array}$ & $\begin{array}{l}\text { Influence DC/DRRO to allocate } \\
\text { for further demand } \\
\text { Influence PIOs to distribute } \\
\text { relief items to designated people }\end{array}$ \\
\hline $\begin{array}{l}\text { Management } \\
\text { of Warehouse/ } \\
\text { Food Godown }\end{array}$ & 24 & $\begin{array}{l}\text { Store received items from DDM/Ministry of } \\
\text { Food and maintain quality } \\
\text { Manage inventory and inform } \\
\text { DDM/Ministry of food about present status } \\
\text { of inventory } \\
\text { Deliver relief items to DC/DRRO office/PIO } \\
\text { as per instruction } \\
\text { Manage manpower to load in truck }\end{array}$ & $\begin{array}{l}\text { Decide schedule of distribution } \\
\text { from Warehouse/Food Godown } \\
\text { as per requisition }\end{array}$ \\
\hline Volunteers & 75 & $\begin{array}{l}\text { Help PIOs to identify actual affected people } \\
\text { Help distribution of reliefs }\end{array}$ & $\begin{array}{l}\text { Share field information with } \\
\text { DC/DRRO/PIO }\end{array}$ \\
\hline $\begin{array}{l}\text { General } \\
\text { affected } \\
\text { People }\end{array}$ & 75 & $\begin{array}{l}\text { Be connected with PIOs/Volunteers } \\
\text { To inform PIOs on items of demand/ actual } \\
\text { requirements } \\
\text { Take shelter in appropriate or designated } \\
\text { location }\end{array}$ & \\
\hline
\end{tabular}

Interviews were conducted by the researchers supported by ten appointed research assistants. The number of participants from each organization were chosen based on i) importance and scope to provide information and suggestion, ii) involvement in the operation, iii) representative of sector of population involved. The participants were specifically asked to analyse existing emergency supply chain operations during specific disaster scenarios within Bangladesh based on their experience in the light of disruption risks. The participants provided constructive suggestions for efficient and responsive supply chains with established structural dynamics. The interviews included the identification of key necessary developments for sustainable ESCs. As each of the participants are from multidisciplinary organizations, their interorganizational processes, whilst aligning with overall government policy, are quite different. However, each organisation follows a very concise and similar focussed mission during disaster scenarios. Researchers have confirmed the criticality of ensuring the reliability and validity of collected data recommending techniques such as the triangulation method (Moon 2019). This research investigated the stakeholders' opinion from three perspectives: method, investigator, and data source. Following the recommendations in Moon (2019), the researchers used several distinct procedures during interviews 
such as, direct questionnaire, observation and discussion. Consistent with previous studies, data was collected from participants working at number of different locations within Bangladesh to ensure validity and reliability of data (Ketokivi \& Choi, 2014; Fernández Campos et al. 2019; Hughes et al., 2020).

The participants were asked about the use of contemporary supply networks operating within Bangladesh during recent disasters to assess the critical disruption risks that are deemed to significantly differ from regular supply chains. A number of key issues relating to the malfunctioning of regular supply chains utilised for disaster management were highlighted in the interviews. The participant transcripts were recorded and analysed in alignment with epistemological and ontological concepts and keywords. The interview content was categorised and restructured in alignment with the principles of matrix thinking (Patton, 1981). This technique helps to breakdown long comments and information into smaller significant variables to develop recognised common concepts and attributes. The participant interview data was categorised to transform the identified problems and recommendations into constructive constructs reflecting pragmatic structural chains relating to ESCs. Specific attributes revealed from qualitative analysis were synchronized and integrated based on commonalities to confirm non-biasness of data. This comprehensive view is summarized in Table 3.

Table 3 Comprehensive Identification of the Respondents regarding Disruption Risks

\begin{tabular}{|c|c|c|c|c|}
\hline $\begin{array}{l}\text { Disruption } \\
\text { Risks }\end{array}$ & Risks Identified & $\begin{array}{l}\text { Significant } \\
\text { Feature }\end{array}$ & $\begin{array}{l}\text { Areas of Structural } \\
\text { Reformation for } \\
\text { Resilient Supply } \\
\text { Chain }\end{array}$ & $\begin{array}{l}\text { Negative Impact } \\
\text { on Sustainability } \\
\text { Parameter }\end{array}$ \\
\hline $\begin{array}{l}\text { Demand side } \\
\text { risks }\end{array}$ & $\begin{array}{l}\text { - Pre-estimated from } \\
\text { historical data } \\
\text { - Actual demand not } \\
\text { assessed } \\
\text { - Demand predicted through } \\
\text { office work, not from field } \\
\text { officer }\end{array}$ & $\begin{array}{l}\text { Both } \\
\text { nonresponsive } \\
\text { and Non- } \\
\text { efficient }\end{array}$ & $\begin{array}{l}\text { - Non-efficient } \\
\text { Functional } \\
\text { structure for } \\
\text { demand } \\
\text { estimation } \\
\text { - Topological } \\
\text { problems - } \\
\text { abandoned } \\
\text { structural } \\
\text { networks }\end{array}$ & $\begin{array}{l}\text { Economic, Social, } \\
\text { and } \\
\text { Environmental }\end{array}$ \\
\hline Supply side risks & $\begin{array}{l}\text { - } \quad \text { Items Pre-selected } \\
\text { - } \quad \text { Actual requirements } \\
\text { reflecting disaster type } \\
\text { ignored } \\
\text { - } \quad \text { Relevant sanitary items } \\
\text { not predicted and } \\
\text { supplied }\end{array}$ & $\begin{array}{l}\text { Non- } \\
\text { responsive }\end{array}$ & $\begin{array}{l}\text { - } \\
\text { pron-responsive } \\
\text { - } \\
\text { Non-responsive } \\
\text { organizational } \\
\text { structure for } \\
\text { procurement }\end{array}$ & $\begin{array}{l}\text { Economic and } \\
\text { Social }\end{array}$ \\
\hline $\begin{array}{l}\text { Regulatory, } \\
\text { legislative, and } \\
\text { administrative } \\
\text { risks }\end{array}$ & $\begin{array}{ll}\text { - } & \text { Authority and } \\
\text { responsibility not } \\
\text { properly aligned } \\
\text { - } \quad \text { Long bureaucratic chain } \\
\text { - } \quad \text { Chief executive office in } \\
\text { the field (DRRO) does not } \\
\text { have direct authority to }\end{array}$ & Non-efficient & 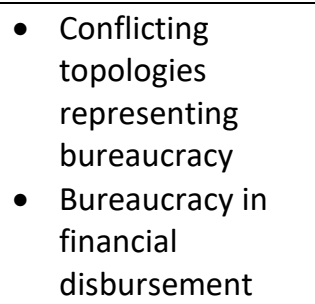 & Economic \\
\hline
\end{tabular}




\begin{tabular}{|c|c|c|c|c|}
\hline & $\begin{array}{l}\text { select inventory, procure, } \\
\text { store, and distribute } \\
\text { - Legal procedure to } \\
\text { estimate demand and } \\
\text { supply is very complicated } \\
\text { and bureaucratic } \\
\text { DRRO does not have } \\
\text { authority to finalize actual } \\
\text { field demand }\end{array}$ & & $\begin{array}{l}\text { - Abandoned } \\
\text { organizational } \\
\text { network } \\
\text { - Non-efficient } \\
\text { Functional } \\
\text { structure in policy, } \\
\text { administration, } \\
\text { and execution }\end{array}$ & \\
\hline $\begin{array}{l}\text { Infrastructure } \\
\text { risks }\end{array}$ & $\begin{array}{ll}\text { - } & \text { Information sharing very } \\
\text { - } & \text { Limited } \\
\text { - } & \text { pogistics management } \\
\text { - } & \text { Remote communication } \\
& \text { very poor } \\
\text { - } \quad \text { Limited transportation } \\
\text { - } \quad \text { Disrupted mobile network } \\
\text { in disaster area }\end{array}$ & Non-efficient & $\begin{array}{l}\text { - Information } \\
\text { sharing structure } \\
\text { non-efficient } \\
\text { - Lack of application } \\
\text { of modern } \\
\text { technology } \\
\text { - Weak structural } \\
\text { network for } \\
\text { distribution }\end{array}$ & $\begin{array}{l}\text { Economic and } \\
\text { Environmental }\end{array}$ \\
\hline $\begin{array}{l}\text { Catastrophic } \\
\text { risks }\end{array}$ & $\begin{array}{l}\text { - } \begin{array}{l}\text { Sudden increase of } \\
\text { demand }\end{array} \\
\text { - } \quad \text { Polluted water } \\
\text { - } \quad \text { Spread of epidemic } \\
\text { disease }\end{array}$ & $\begin{array}{l}\text { Both } \\
\text { nonresponsive } \\
\text { and inefficient }\end{array}$ & $\begin{array}{l}\text { - Non-efficient } \\
\text { organizational, } \\
\text { functional, } \\
\text { financial, and } \\
\text { information } \\
\text { structure }\end{array}$ & $\begin{array}{l}\text { Economic and } \\
\text { Environmental }\end{array}$ \\
\hline $\begin{array}{l}\text { Interoperability } \\
\text { risks }\end{array}$ & $\begin{array}{l}\text { - No common platform } \\
\text { among the working } \\
\text { organizations } \\
\text { - } \quad \text { No interoperable protocol } \\
\text { - Conflicting } \\
\text { administrations among } \\
\text { organizations } \\
\text { Demand estimation, } \\
\text { inventory selection, and } \\
\text { distribution - all } \\
\text { scattered } \\
\text { During emergency, no } \\
\text { coordination }\end{array}$ & $\begin{array}{l}\text { Both } \\
\text { nonresponsive } \\
\text { and inefficient }\end{array}$ & $\begin{array}{l}\text { - Non-robust } \\
\text { structural topology } \\
\text { among } \\
\text { organizations } \\
\text { - Absence of } \\
\text { application of } \\
\text { technology to } \\
\text { establish common } \\
\text { protocol } \\
\text { - Redundant in } \\
\text { functional } \\
\text { structure among } \\
\text { organizations }\end{array}$ & $\begin{array}{l}\text { Economic, Social, } \\
\text { and } \\
\text { Environmental }\end{array}$ \\
\hline $\begin{array}{l}\text { Storage and } \\
\text { facility location } \\
\text { risks }\end{array}$ & $\begin{array}{l}\text { Warehouses located } \\
\text { based on procurement, } \\
\text { not decentralized } \\
\text { No alternative facilities } \\
\text { for emergency } \\
\text { - Sometimes warehouses } \\
\text { affected by flood } \\
\text { - Long lead time to } \\
\text { distribute } \\
\text { Control of Warehouse } \\
\text { very bureaucratic }\end{array}$ & Non-efficient & 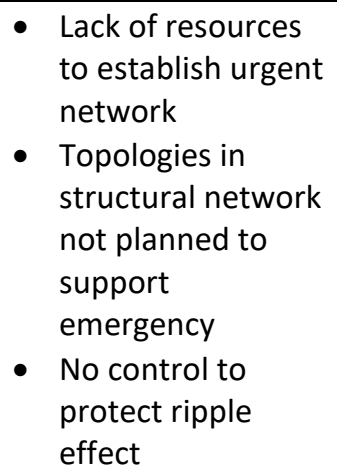 & $\begin{array}{l}\text { Economic and } \\
\text { Environmental }\end{array}$ \\
\hline
\end{tabular}




\section{Results and Interpretation}

The results highlight a number of supply chain disruption risks associated with distributing relief supplies during a disaster scenario. In the context of demand side risks, the traditional quota of supplies for people in need is traditionally assessed based on historical data. However, this is not sufficient during a disaster situation, especially in the era of modern technology where actual demand could be identified quickly and communicated directly to procurement agencies in real time. Demand side risks can increase in affected areas due to the rapid increase in urgent need for clean water and food supplies, particularly the need for adequate sanitation and water purification systems. Researchers analysing humanitarian supply chains during disaster scenarios exhibit similar findings (Beamon \& Balcik, 2008; Dwivedi et al., 2018). Therefore, for this category of disruption risks and consequent ripple effect, the networks of emergency supply chains should be arranged with different dynamics where field officers (executing agencies) should be empowered to estimate and communicate with procurement agencies without unnecessary bureaucratic resistance.

Considering supply side risks, one important aspect which should be addressed, is that disaster affected people might have different requirements for relief supplies. For example, during flood, water purification tablets are extremely important and excessive demand can create further issues due to rapid expansion of water polluted diseases. The traditional historical demand procurement model, although operationally adequate during standard procure and supply cycles, is unable to manage excessive demand outside of these parameters.

We can address a number of key risks associated with traditional supply chain disruption and their ability to manage emergency scenarios. These are regulatory, legislative, administrative and interoperability threats. The threats to the operation of supply chains from these types of risk, are the major reasons for the inefficient operation of supply chains within Bangladesh. In the phases of assessment, procurement, inventory selection, storage, and distribution during a disaster, a significant number of organizations participate, but operate under different functional structures and protocols. Organizations often do not cooperate effectively, fail to share information and tend not to work within a cohesive infrastructure during procurement and distribution. Multiple networks that operate to distribute supplies, often create longer lead times, operate poor logistics, exhibit poor supply chain connectivity, and incur higher costs due to poor management support (Dubey et al. 2019ab; Dwivedi et al. 2018; Shibin et al. 2017). Structural networks among the different organizations should be managed through a single nodal point in the supply chain, with common agreed protocols suitable for interoperability (Dwivedi et al. 2018; Kahn, 2008).

Infrastructure is a vital issue for any supply chain. However, its importance is critical during a disaster situation due to the need to efficiently distribute badly needed supplies (Alessandra, 2012; Balcik et al., 2010). During any natural disaster, Information and Communication Technology (ICT), road and river communication, electricity and mobile phone communication can significantly deteriorate compounding any ripple effect on the performance of the supply chain. Improving these aspects by delegating authority to the field officers (PIOs) and organising local storage and transportation systems can potentially mitigate these disruption risks (Shareef et al., 2020). During any natural disaster, threats to the disruption of the 
supply chain can increase due to catastrophic incidents and threats to human health stemming from poor sanitation and lack of clean water. Efficiency in selection of supplies, additional local storage, distribution and efficient lead time management, are key supply chain parameters that can be improved. Several researchers supported this finding (Ali et al., 2017; Diniz \& Fabbe-Costes, 2007). These threats can create further risks along the supply chain the can severely impact the ability of supplies to get to those in need (Altay \& Labonte, 2014).

Storage and facility location risks have serious compounding effect on several other parameters of supply chain such as: logistics management, manpower, distribution, and managing lead-time from procurement to distribution. Efficiency and responsiveness of supply chain - both are closely connected with storage and facility location risks. Researchers have identified the positive impact from instigating a reliable facility location with multiple stores that can potentially minimize disruption risks for emergency supply chains (Berman et al., 2007; Blackhurst et al., 2005; Cavinato, 2004; Cui et al., 2012; Garcia-Garcia et al., 2015; Wagner \& Bode, 2008). Efficient and effective inventory management can be developed if the supply chain can be operated through several alternative facility locations (Ivanov et al., 2016). In this scenario the structural networks of traditional supply chain structure shown in Figure 1 needs to be re-engineered to cater for the change in dynamics for ESCs. Although the location of the multiple facility is critical, the authority to procure additional supplies from warehouses and food Godown should be formalised to the nominated responsible management (In our case, DRRO is the actual functional authority). To design an effective ESC for relief distribution in affected areas, the relocation and delegated authority for local decision making is significantly important where considerations such as multiple storage locations to mitigate the impacts from single warehouse flooding due to their proximity to disaster locations. (Balcik et al., 2010; Dwivedi et al. 2018).

A potential and significant difference in estimation complexity of ESC when compared to regular supply chains, is the abrupt fluctuation in demand as the disaster unfolds and the true extent of the emerging demand (Dubey et al., 2015). Within Bangladesh, currently no demand assessment from the affected areas within the disaster location is conducted. Demand for supplies are estimated based on historical statistics. This working practice can necessitate a critical gap between supply and demand which in turn creates a ripple effect in relief distribution with resulting dire consequences for the people affected. Disaster management in any country should be structured to meet economic and logistics viability, cater for health and social demands and ensure environmental security (Beamon \& Balcik, 2008; Bui et al., 2000). The supply and demand risks associated with ESC necessitate a change in the structural topology of procurement and distribution to ensure a resilient supply chain. The majority of the respondents highlighted structural reformation as a key factor in assessing demand, procurement, and supply. This suggestion is supported by the study conducted by Diniz and Fabbe-Costes (2007).

\section{Discussion}

To operate any supply chain during a natural disaster scenario where multidisciplinary organizations attempt to work together, each exhibiting different organisational, regulatory, legislative and administrative characteristics is a complex and risky undertaking (Bui et al., 2000; Dwivedi et al. 2018). In 
terms of resilient structural dynamics, major problems were revealed due to a number of distinct disruption risks. There are several redundant elements to the existing supply chain network that cause longer lead times from procurement to inventory management and from logistics management to distribution. The most common issue stems from high levels of bureaucracy and ineffective delegation of authority for timely decision making. This complex bureaucracy and illogical delegation of authority results in a very inefficient and unsustainable supply chain unable to react to the demand of major disasters.

The weakness in information sharing, behavioural uncertainty and interoperability among the organizations generates a ripple effect caused by multidisciplinary disruption risks. This is evidenced by mismanagement of operations, poor cooperation amongst the organizations, and excess supply of certain items whilst key essential items are in short supply. Furthermore, the study shows that reduction can act as an enabler for swift trust. This finding is asserted by extant literature on conflict management in coordination of supply chain (Dubey et al., 2015; Labonte, 2014).

Figure 3 highlights a revised supply chain architecture structured to cater for the key demands of an effective ESC within the Bangladesh ESC context based on the feedback from the interviews with the participants. 


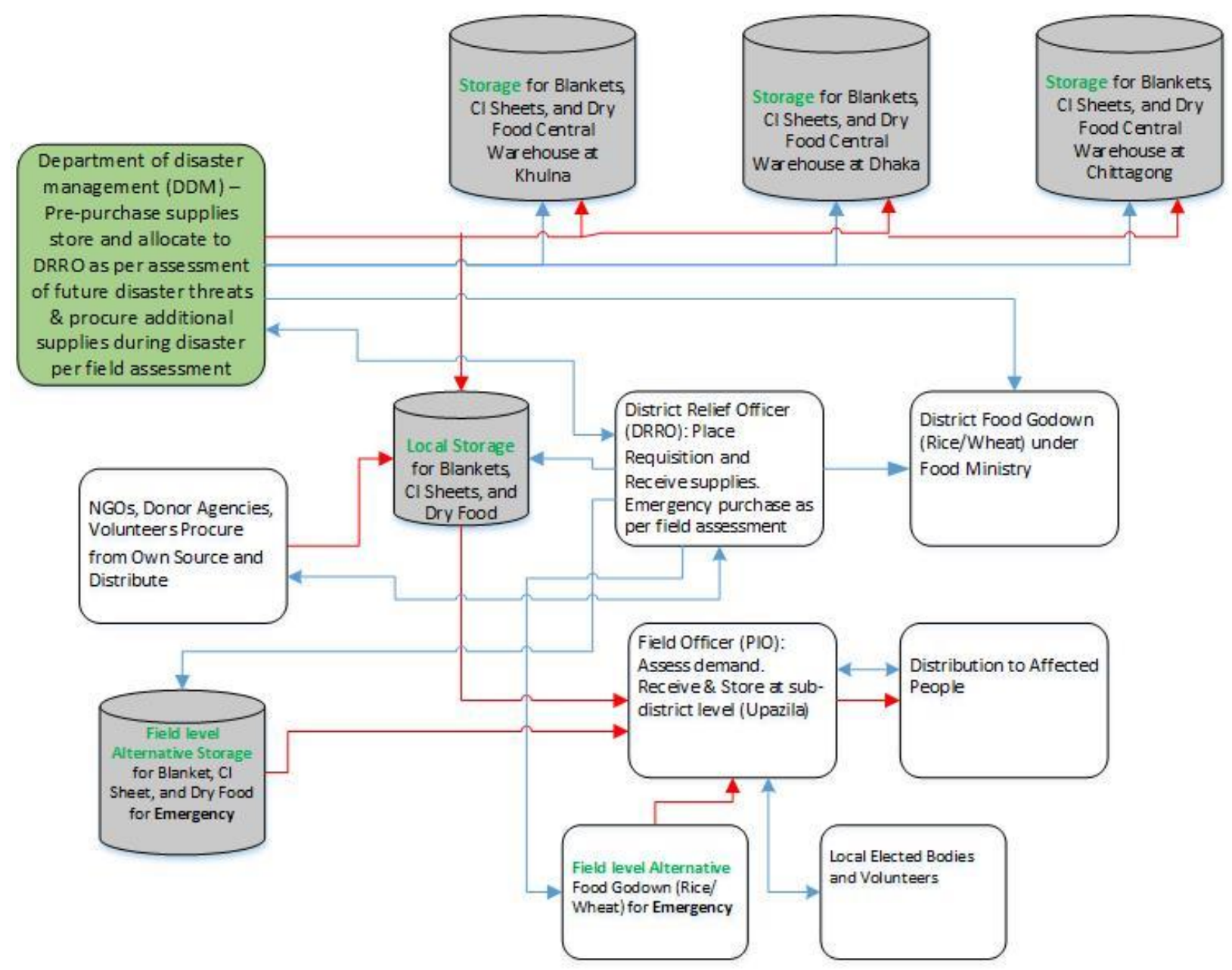

Figure 3: Sustainable Emergency Supply Chain (Blue arrow for Communication/Instruction, Red arrow for Delivery)

The key changes within the presented ESC in Figure 3 over existing supply chains are as follows:

- Reduced levels of central authority and streamlined bureaucracy for local decision making.

- Addition of local field level alternative storage of essential supplies via decentralised warehousing infrastructure

- NGOs are more integrated within the disaster management infrastructure.

- Restructured DDM procurement to cater for in-disaster needs not just reliant on historical data.

- Local needs assessment is managed via closer integration from field officers (PIO) to the demands of the affected people.

- Restructuring of DRRO to more efficiently organise requisition of supplies as per emergency needs assessment.

- More efficient and reactive supply management and logistics from field officers (PIO) to local storage in response to local demand. 
- Reorganisation of food Godown to offer a field level alternative to better react to disaster requirements.

The changes to the existing supply chain via the revised model in Figure 3 reflect the many issues within the existing infrastructure as highlighted by the participants and the suggested changes are positioned to offer increased support to disaster scenarios within Bangladesh. Studies on humanitarian supply chain in different countries (Alessandra, 2012; Balcik et al., 2010; Beamon \& Balcik, 2008; Dwivedi et al., 2018; Gebresenbet \& Bosona, 2012; Jayaram et al., 2000; Shareef et al., 2019) have asserted and recommended several changes that have been articulated in this study. Problems in cooperation, administration, and facility locations revealed in this field study have demonstrated similar experiences from past studies on emergency supply chain during disaster scenarios (Beamon \& Balcik, 2008; Bui et al., 2000; Labonte, 2014). These recommendations for the revisions of emergency supply chains are also supported by scholarly articles on disruption risks and ripple effect (Cui et al., 2010; Dolgui et al., 2018; Dubey et al. 2019ab; Dwivedi et al. 2018; Ivanov, 2018; Shibin et al. 2017).

Existing supply chains operating in Bangladesh have substantial weaknesses in terms of sustainability in the context of environmental, economic, and infrastructure related issues. Many of these issues relating to the ability of national and local supply chains to operate under disaster management conditions, highlight the critical aspects of a robust infrastructure for timely information sharing, dynamic communication, organized logistics management, empowerment of executive bodies to manage transportation, application of technology and widespread use of mobile communication as key factors to mitigate supply chain risks are referenced within the literature (Balcik et al., 2010; Dwivedi et al. 2018; Lee et al., 1993). Previous studies have highlighted many of these issues as limiting factors in establishing an economically and environmentally sustainable resilient supply chain specifically within Bangladesh (Dwivedi et al. 2018). The many issues and inherent complexities have been highlighted by the participants as key barriers to the efficient workings of the supply chain. As highlighted in Shareef et al. (2018) the location of suitable warehousing and storage facilities are influenced by the demands and control of central procurement. However, the operation of the supply chain during a disaster does not currently comply with centrally controlled norms and effective bureaucracy. Researchers have posited the merits of mitigating disruption risks by utilising multiple geographically dispersed storage facilities (Beamon \& Balcik, 2008; Berman et al., 2007; Blackhurst et al., 2005; Cui et al., 2012; Wagner \& Bode, 2008). The criticality of information sharing, and infrastructure development are very important for resilient supply chains operated during disaster scenarios. In this context as posited in Diallo et al. (2017), instigating a process of streamlining all the participating organizations through a central coordination committee is extremely important for interoperability to reduce ripple effect during disasters. Researchers that have studied disruption risks (Hu et al., 2013; Ivanov et al., 2016), ripple effect (Dolgui et al., 2018; Ivanov et al., 2014), structural dynamics (Cui et al., 2010; Ivanov, 2018), sustainability of supply chain (Dubey et al., 2017), and operation of emergency supply chain (Dubey et al., 2014; Dwivedi et al., 2018) have revealed different aspects of these problems from a number of alternative perspectives, however, the specific findings of this study can find strong support from the directions of the aforementioned literature. 


\subsection{Implications for Theory}

The identification of disruption risks and sequential ripple effect associated with emergency supply chains during disaster management has significant implications for academics and multidisciplinary organizations. We assert that this study offers new insight to the multitude of complexities inherent within the operation of traditional supply chains within an emerging market perspective where the inability of existing networks to cater for the critical demands needed for disaster management is highlighted.

For academics, whilst addressing and describing problems and conceptualizing associated disruption risks within supply chains, particularly within the emerging market context, insight can be gained from the reflections on this unique ripple effect of ESCs. Supported by previous studies (Campos et al., 2019; Dolgui et al., 2018; Sodhi et al., 2012; Blackhurst et al., 2005; Wagner \& Bode, 2008) it is evident from this research that structural dynamics, particularly topologies of networks are significantly different and thus, should be restructured taking account of the unique circumstances and demands of ESCs The impacts of structural dynamics, disruption risks, and sequential reasons of ripple effect are addressed and we assert that the distinct effect, unique type, and versatile impact on emergency disaster management can open new avenues for research and can contribute to the existing literature in the design of resilient ESCs.

Balcik and Beamon (2008) demonstrated that the selection and integration of existing facility locations within emergency structures exhibits implications for the management of humanitarian relief. Their key findings recognized the inefficiency of humanitarian relief distribution. While analysing the causes of inefficiencies within emergency relief management through central management, Dwivedi et al. (2018) discussed some inevitable weaknesses in several areas integrated operations, for instance, interoperability, inter-organizational cooperation, conflicts, top-down management, and poor demand estimation. Altay and Labonte (2014) articulated the poor management of emergency supply chain during disaster due to absence of proper information sharing and overall information management. This research aligns with these findings where we identify a number of redundant elements to the existing supply chain network that cause longer lead times exacerbated by the complex bureaucracy, poor delegation of authority, inadequate communications infrastructure and strategy, where inevitably a very inefficient and unsustainable supply chain is unable to react to the demands of major disasters within Bangladesh. Critically, during any emergency the primary challenge is to share information and accumulate overall knowledge from all the impacted stakeholders. Dubey et al. (2017a) focused on many of these issues in the context of supply chain resilience supporting the key findings of this research. Although the studies by Ivanov et al., (2014) and Dolgui et al. (2018) address disruption risks in supply chains and its impact on structural dynamics, these topics within an emergency supply chain context, seem to be generally absent from the wider literature, highlighting the contribution from this research.

By using the findings from this research, academics can provide additional focus on several aspects of emergency supply for resilience which can contribute to structural dynamics and supply chain theory. The following propositions can be drawn for future researchers: 
- Authority decentralization is one of the prime requirements for designing resilient supply chain during disaster. Centralized authority cannot manage sources of field level causes of disruption risks.

- If field level threats to disruption are not well coordinated and timely managed, disruption risks will be propagated, causing ripple effects within supply chain operations. Field level risks should be managed at source.

- Demand estimation is one of the fundamental causes of disruption risks in operation of both procurement and distribution during emergency. Historical data should be the primary source of procurement.

- Designing facility locations during procurement and distribution is another unique issue for efficient operation of emergency supply chain. Allocated resources for traditional supply chain in terms of storage facilities, cannot meet emergency operation where lead time for distribution is one of the primary parameters for effectiveness.

- Interoperability is an essential prerequisite for setting a stable but robust structural dynamic supply chain. Information management and sharing and inter-organizational management systems should be designed considering emergency operation, not based on administrative authority.

\subsection{Implications for practice}

We posit that practitioners can gain new insight to the many issues and barriers to the efficient operation of ESCs specific to Bangladesh but will have equal resonance with other countries constrained by similar issues relating to infrastructure and resources. This study highlights the limitations of managing the planning for disasters based on historical data and reliance on existing supply chain infrastructure to cater for disaster scenarios. This approach has proved to be inflexible and inefficient where regional bureaucratic processes do not facilitate effective local priorities on the ground. The results highlight the criticality of field level decision making and local insight to better mitigate disruption risks. Item selection, field estimation based on actual requirement, and procurement have a profound impact on the sustainability of ESCs. The criticality of information sharing, and infrastructure development are also very important for resilient supply chain operation during a disaster. The streamlining of all the participating organizations through a central coordination committee is extremely important for interoperability to reduce the ripple effect on the people impacted by the disaster and critical recommended change for authorities and decision makers. This point is supported by the wider literature (Cui et al., 2012; Blackhurst et al., 2005; Sodhi et al., 2012; Wagner \& Bode, 2008) were studies have recommended decentralization of storage and development of alternative facilities. This has a compounding effect on the success of ESCs, where many warehouses might be unusable due to flood water, inaccessibility, and broken infrastructure. Therefore, a sustainable emergency supply chain should consider the well-designed establishment of decentralized warehouses to improve the disaster management process. 
Considering the most significant disruption threats associated with any supply chain such as, demand side risks, supply side risks, regulatory, legislative, and administrative risks, infrastructure risks, catastrophic risks, interoperability risks, and storage location risks, this study has analysed the actual scenario of different risks from relevant case studies on past disaster management operations which can provide specific knowledge of operational inefficiency in emergency supply chains of use to practitioners. The case studies posit the many issues and inability of authorities to adequately manage the inherent complexities within emergency supply chains during disaster scenarios. The responses on the lived-in day to day realities of managing the myriad issues and inabilities of existing supply chains to cope with disaster scenarios, have been documented and assessed. The analysis of this participant data and the subsequent adapted Sustainable Emergency Supply Chain infrastructure process presented in Figure 3, could be of key benefit to practice within an emerging economy context.

\subsection{Limitation and Future Research Direction}

As an exploratory study with extensive interviews, this research has some limitations. It could be viewed that members who participated in the interviews could perhaps have elements of subconscious bias or conflicting interest. However, the large sample size with varying data capture procedures is likely to somewhat mitigate the impact of this issue. This study was conducted within Bangladesh and therefore the findings reflect the inherent bureaucracy and cultural context of the country. This single country limitation could be mitigated via further research to ascertain the findings of further developing countries to offer a richer set of comparable results. Inter-organizational conflicts have been thoroughly investigated and considered, however, inside any single organization, there are enormous reasons of administrative disputes among the members of the same organization. The consideration and systematic views of all members of any single organization could be erroneous when not balanced by the views of a comparable organization. This was not considered during the study and could form the basis of further research.

\section{Conclusions}

This study explores the inherent complexities and significant challenges in the operation of supply chains during emergency scenarios within Bangladesh and the consequential impact on large numbers of people. The concept of the ESC and its divergence from regular supply chains is addressed in the context of disruption risks and structural dynamics via the analysis of a number of Bangladesh disaster case studies. We utilise the views and opinions of over 500 stakeholder participants directly involved in the support and operation of disaster efforts within Bangladesh. Considering the profound impact of disruption risks on supply chains due to significant differences in operation, demand estimation, supply selection, procurement, logistics management, inventory management, distribution, and interoperability among organizations, we highlight that operating an ESC through regular networks can create significant disruption risks and inevitable instability within structural dynamics. We present an adapted ESC infrastructure that offers a more streamlined approach to needs based disaster support where decision making and rapid provision of supplies are managed at the local level. 


\section{References}

ADRC (Asia Disaster Reduction Centre), (2019). Information on disaster risk reduction of the member countries. https://www.adrc.asia/nationinformation.php?NationCode=50\&Lang=en\&Mode=country

Alessandra., C. (2012). Humanitarian Logistics: Cross-sector Cooperation in Disaster Relief Management, Chapter-2, Page-13, Springer.

Ambulkar, S., J. Blackhurst, and S. Grawe. 2015. Firm's Resilience to Supply Chain Disruptions: Scale Development and Empirical Examination. Journal of Operations Management 33-34 (34): 111-122.

Altay, N., \& Labonte, M. (2014). Challenges in humanitarian information management and exchange: Evidence from Haiti. Disasters, 38(S1), S50-S72.

Balcik, B. \& Beamon, B.M., (2008), Facility location in humanitarian relief. International Journal of Logistics: Research and Applications, 11 (2), 101-121.

Balcik, B., Beamon, B.M., Krejci, C.C., Muramatsu, K.M., \& Ramirez, M., (2010). Coordination in humanitarian relief chains: Practices, challenges and opportunities, International Journal of Production Economics, 126 (1), 22-34.

Beamon, B. M., \& Balcik, B. (2008). Performance measurement in humanitarian relief chains. International Journal of Public Sector Management, 21(1), 4-25.

Berman, O., Krass, D. and Menezes, M.B.C. (2007) Facility reliability issues in network P-median problems: strategic centralization and co-location $\mathrm{e}^{\circledR}$ ects. Operations Research, 55: 332-350.

Blackhurst, J., C. W. Craighead, D. Elkins, R. B. Handfield. 2005. An empirically derived agenda of critical research issues for managing supply-chain disruptions. Int. J. Prod. Res 43(19): 4067-4081.

Blackhurst, J., K. S. Dunn, and C. W. Craighead. (2011). An empirically derived framework of global supply resiliency. Journal of Business Logistics 32(4): 374-391.

Campos, P. F.,, Trucco, P., \& Huaccho Huatuco, L. (2019). Managing structural and dynamic complexity in supply chains: insights from four case studies. Production Planning \& Control, 1-13.

Bui, T., Cho, S., Sankaran, S., \& Sovereign, M. (2000). A framework for designing a global information network for multinational humanitarian assistance/disaster relief". Information Systems Frontiers, $1(4), 427-442$.

Cavinato, J. L. 2004. Supply chain logistics risks: From the back room to the board room. International Journal of Physical Distribution \& Logistics Management, 34(5): 383-387.

Chopra, Sunil and ManMohan S. Sodhi (2004), "Managing Risk to Avoid Supply-Chain Breakdown, Sloan Management Review, 46(1), 53-61.

Coleman, Les (2006), "Frequency of Man-Made Disasters in the 20th Century," Journal of Contingencies and Crisis Management, 14(1),pp. 3-11.

Cui, T., Ouyang, Y., Shen, Z.-J.M., 2010. Reliable facility location design under the risk of disruptions. Operations Research 58 (4-Part-1), 998-1011.

Davis, L. B., F. Samanlioglu, X. Qu, and S. Root. (2013). Inventory Planning and Coordination in Disaster Relief Efforts. International Journal of Production Economics 141 (2): 561-573. 
Diallo, C., Venkatadri, U., Khatab, A., \& Bhakthavatchalam, S. (2017), State of the art review of quality, reliability and maintenance issues in closed-loop supply chains with remanufacturing. International Journal of Production Research, 55(5), 1277-1296.

Disaster Management Bureau. (2015). National plan for disaster management, standing orders on disaster. Government of the People's Republic of Bangladesh.

Dolgui A., Ivanov D., Sokolov B. (2018). Ripple effect in the supply chain: An analysis and recent literature. International Journal of Production Research, Invited Special Issue $55^{\text {th }}$ Volume Anniversary of IJPR, 56(1-2), 414-430.

Dreyer, H. C.,Strandhagen, J. O., Hvolby, H-H., Romsdal, A., \& Alfnes, E., (2016) Supply chain strategies for specialty foods: a Norwegian case study, Production Planning \& Control, 27:11, 878-893.

Dwivedi, Y. K., Shareef, M. A.,Mukerji, B., Rana, N. P. \& Kapoor, K. K. (2018), Involvement In Emergency Supply Chain For Disaster Management: A Cognitive Dissonance Perspective, International Journal of Production Research, 56(21), 6758-6773.

Dubey, R., Ali, S. S., Aital, P., \& Venkatesh, V. G. (2014). Mechanics of humanitarian supply chain agility and resilience and its empirical validation. International Journal of Services and Operations Management, 17(4), 367-384.

Dubey, R., Gunasekaran, A., Papadopoulos, T., Childe, S., Shibin, K., Wamba, S., (2017). Sustainable supply chain management: framework and further research directions. Journal of Cleaner Production, 142 (Part 2), 1119-1130.

Dubey, R., Gunasekaran, A., \& Papadopoulos, T. (2019a). Disaster relief operations: past, present and future. Annals of Operations Research, 283(1-2), 1-8.

Dubey, R., Gunasekaran, A., Childe, S. J., Fosso Wamba, S., Roubaud, D., \& Foropon, C. (2019b). Empirical investigation of data analytics capability and organizational flexibility as complements to supply chain resilience. International Journal of Production Research, 1-19.

Dubey, R., Altay, N., \& Blome, C. (2019c). Swift trust and commitment: The missing links for humanitarian supply chain coordination? Annals of Operations Research, 283(1), 159-177

Dubey, R., Gunasekaran, A., Bryde, D. J., Dwivedi, Y. K., \& Papadopoulos, T. (2020). Blockchain technology for enhancing swift-trust, collaboration and resilience within a humanitarian supply chain setting. International Journal of Production Research, 1-18.

Garcia-Garcia, G., Woolley, E., Rahimifard, S., 2015. A framework for a more efficient approach to food waste management. Int. J. Food Eng. 1 (1), 65e72.

Gopal, P. R. C., and J. Thakkar. 2016. "Analysing Critical Success Factors to Implement Sustainable Supply Chain Practices in Indian Automobile Industry: A Case Study." Production Planning and Control, 27 (12): 1005-1018.

Gunasekaran, A., Dubey, R., Fosso Wamba, S., Papadopoulos, T., Hazen, B. T., \& Ngai, E. W. (2018). Bridging humanitarian operations management and organisational theory. International Journal of Production Research, 56(21), 6735-6740.

Gupta W., He B., Sethi S.P. (2015). Contingent sourcing under supply disruption and competition. International Journal of Production Research, 53(10), 3006-3027. 
Hishamuddin, H., Sarker, R.A., \& Essam, D. (2013). A recovery model for a two-echelon serial supply chain with consideration of transportation disruption. Computers and Industrial Engineering, 64 (2), 552561.

Hou, J., Zeng, A.Z., \& Zhao, L. (2010). Coordination with a backup supplier through buy-back contract under supply disruption. Transportation Research Part E: Logistics and Transportation Review, 46(6), 881895.

Hu, X, Gurnani, H, \& Wang L. (2013). Managing risk of supply disruptions: Incentives for capacity restoration. Production and Operations Management, 22(1),137-150.

Hughes, D. L., Rana, N. P., \& Dwivedi, Y. K. (2020). Elucidation of IS project success factors: an interpretive structural modelling approach. Annals of Operations Research, 285(1), 35-66.

Islam, M. A., Islam, M. S., \& Islam, T. (2017, September). Landslides in chittagong hill tracts and possible measures. In International Conference on Disaster Risk Mitigation, Dhaka, Bangladesh.

Ivanov, D., Sokolov B., Kaeschel J. (2010) A multi-structural framework for adaptive supply chain planning and operations control with structure dynamics considerations, European Journal of Operational Research, 200(2), 2010, pp. 409-420.

Ivanov D., Sokolov B., Pavlov A., Dolgui A., and Pavlov D. (2016). Disruption-driven supply chain (re)planning and performance impact assessment with consideration of pro-active and recovery policies. Transportation Research: Part E, 90, 7-24.

Kahn, M. S. A. (2008). Disaster preparedness for sustainable development in Bangladesh. Disaster Prevention and Management, 17(5), 662-671.

Knemeyer, A. M., W. Zinn, and C. Eroglu. 2009. Proactive Planning for Catastrophic Events in Supply Chains. Journal of Operations Management 27 (2): 141-153.

Kouvelis, P., and J. Li. (2012). Contingency Strategies in Managing Supply Systems with Uncertain Leadtimes. Production and Operations Management, 21 (1): 161-176.

Kumar, A., Singh, J. P., Dwivedi, Y. K., \& Rana, N. P. (2020). A deep multi-modal neural network for informative Twitter content classification during emergencies. Annals of Operations Research, 132.

Lee, Hau L. and Billington, C. (1993), Material Management in Decentralized Supply Chains, Operations Research, 41(5), 835-847.

Lewis, B. M., A. L. Erera, M. A. Nowak, and C. C. White, III. (2013). Managing Inventory in Global Supply Chains Facing Port-of-Entry Disruption Risks. Transportation Science 47 (2): 162-180.

Li, Q., B. Zeng, and A. Savachkin. (2013). Reliable Facility Location Design under Disruptions. Computers \& Operations Research 40 (4): 901-909.

Lim, M., M. S. Daskin, A. Bassamboo, and S. Chopra. (2010). A Facility Reliability Problem: Formulation, Properties and Algorithm. Naval Research Logistics 57 (1): 58-70.

Lim, M. K., A. Bassamboo, S. Chopra, and M. S. Daskin. 2013. Facility Location Decisions with Random Disruptions and Imperfect Estimation. Manufacturing and Service Operations Management, 15 (2): 239-249.

Manuj, I., J. T. Mentzer. (2008). Global supply chain risk management. J. Bus. Logist 29(1): 133-155. 
McKinnon, Alan (2006), Life Without Trucks: The Impact of a Temporary Disruption of Road Freight Transport on a National Economy, Journal of Business Logistics, 27(2), 227-250.

McLachlin, R., \& Larson, P. D. (2011).Building humanitarian supply chain relationships: lessons from leading practitioners. Journal of Humanitarian Logistics and Supply Chain Management, 1(1), 3249.

Moktadir, M. A., Rahman, T., Rahman, M. H., Ali, S. M., \& Paul, S. K. (2018). Drivers to sustainable manufacturing practices and circular economy: A perspective of leather industries in Bangladesh. Journal of cleaner production, 174, 1366-1380.

Norrman A, Jansson J. (2004), Ericsson's proactive supply chain risk management approach after a serious sub-supplier accident. International Journal of Physical Distribution and Logistics Management, 35(5):434-53.

Oke, A., M. Gopalakrishnan. 2009. Managing disruptions in supply chains: A case study of a retail supply chain. Int. J. Prod. Econom. 118(1): 168-174.

Patton, M. Q. (1981). Creative evaluation. San Anselmo: Sage.

Rao, S., T. J. Goldsby, D. lyengar. 2009. The marketing and logistics efficacy of online sales channels. International Journal of Physical Distribution \& Logistics Management, 39(2): 106-130.

Sarker, M. N. I., Bingxin, Y., Sultana, A., \& Prodhan, A. S. (2017). Problems and challenges of public administration in Bangladesh: pathway to sustainable development. International Journal of Public Administration and Policy Research, 2(1), 008-015.

Shareef, M. A., Dwivedi, Y. K., Mahmud, R., Wright, A., Rahman, M. M., Kizgin, H., \& Rana, N. P. (2019). Disaster management in Bangladesh: developing an effective emergency supply chain network. Annals of Operations Research, 283(1), 1463-1487.

Shareef, M. A., Dwivedi, Y. K., Kumar, V., Mahmud, R., Hughes, D. L., Rana, N. P., \& Kizgin, H. (2020). The inherent tensions within sustainable supply chains: a case study from Bangladesh. Production Planning \& Control, 1-18.

Shibin, K. T., Dubey, R., Gunasekaran, A., Hazen, B., Roubaud, D., Gupta, S., \& Foropon, C. (2017). Examining sustainable supply chain management of SMEs using resource based view and institutional theory. Annals of Operations Research, 1-26.

Sinha, A., Kumar, P., Rana, N. P., Islam, R., \& Dwivedi, Y. K. (2019a). Impact of internet of things (IoT) in disaster management: a task-technology fit perspective. Annals of Operations Research, 283(1-2), 759-794.

Singh, J. P., Dwivedi, Y. K., Rana, N. P., Kumar, A., \& Kapoor, K. K. (2019b). Event classification and location prediction from tweets during disasters. Annals of Operations Research, 283(1), 737-757.

Sodhi, M.S. (2005). Managing demand risk in tactical supply chain planning for a global consumer electronics company. Production and Operations Management 14, 69-79.

Sodhi, M.S., Son, B.G, Tang, C.S. (2012). Researchers' perspectives on supply chain risk management. Production and Operations Management, 21, 1-13.

Tang, C. S., B. Tomlin. (2008). The power of flexibility for mitigating supply chain risks. Int. J. Prod. Econom. 116(1): 12-27. 
Tayal, A., Gunasekaran, A., Singh, S. P., Dubey, R., \& Papadopoulos, T. (2017). Formulating and solving sustainable stochastic dynamic facility layout problem: A key to sustainable operations. Annals of Operations Research, 253(1), 621-655.

Tomasini, R., L. Van Wassenhove. (2009). Humanitarian Logistics. McMillan Publishers, London, UK.

Wagner, S. M., C. Bode. (2008). An empirical examination of supply chain performance along several dimensions of risk. Journal of Business Logistics, 29(1): 307-325.

Wamba, S. F., Gunasekaran, A., Dubey, R., \& Ngai, E. W. (2018). Big data analytics in operations and supply chain management. Annals of Operations Research, 270(1-2), 1-4. https://link.springer.com/article/10.1007/s10479-018-3024-7 